\title{
PEMBELAJARAN APRESIASI SASTRA MELALUI PENDEKATAN KOMUNIKATIF BERBASIS KOOPERATIF DAN IMPLIKASINYA TERHADAP PENDIDIKAN KARAKTER
}

\author{
Literature Appreciation Learning through Communicative Approach Base on \\ Cooperative and Its Implication towards Character Building
}

\author{
Abdul Salam \\ SMK Negeri 3 Banjarbaru \\ Jalan Banua Praja Utara, Cempaka, Banjarbaru 70733 Kalimantan \\ Selatan.Telepon (0511) 67350000, Pos-el: smkn3banjarbaru@yahoo.co.id \\ hp: 081251218139
}

\begin{abstract}
Astrak: Penelitian ini bertujuan untuk mengetahui pelaksanaan pembelajaran sastra melalui pendekatan komunikatif berbasis kooperatif dan implikasinya terhadap pendidikan karakter siswa kelas XII Busana Butik (BB) SMKN 3 Banjarbaru. Pengumpulan data dilakukan dengan menggunakan caratrianggulasi meliputi, tes, angket, dan pengamatan. Hasil penelitian yang dianalisis secara kualitatif dan kuantitatif menunjukkan fakta bahwa, rerata kemampuan siswa menganalisis karya sastra sebelum dilaksanakan tindakan hanya mencapai 46,61. Setelah diberikan tindakan melalui pendekatan komunikatif berbasis pembelajaran kooperatif, kemampuan mengapresiasi sastra siswa meningkat menjadi 74,81 pada siklus I dan 76,81 pada siklus II. Implikasinya terhadap pendidikan karakter, pendekatan komunikatif berbasis kooperatif yang diterapkan pada pembelajaran sastra ternyata memberikan penguatan karakter peserta didik dengan meningkatnya capaian nilai karakter B, yang pada siklus I kurang dari 75 \% menjadi lebih dari $75 \%$ pada siklus II.
\end{abstract}

Kata kunci: Pendidikan karakter, pembelajaran sastra, dan pendekatan komunikatif kooperatif.

\begin{abstract}
The objective of the study is to find out the literature appreciation learning through communicative approach base on cooperative and its implication towards character building at XII BB class SMKN 3 Banjarbaru. The data collection is done through triangulation using questionnaires, tests, and observation. The results of the study which is analyzed qualitatively and quantitatively shows that the average score of students in analyzing literature before the activity is applied is only 46,61. After conducting the approach, the students' average score in analyzing the literature work increased into 74,81 in cycle I and 76,81 in cycle II. The implication towards the character building is that the communicative approach based on the cooperative learning in the literature study gives the enforcement to the students' character. It can be seen by the increasing number of students who achieved B score. In cycle I less than 70\% students could achieve B then it increased to $75 \%$ in cycle II.
\end{abstract}

Keywords: Character buliding, literature study, communicative - cooperative approach.

\section{PENDAHULUAN}

Sastra merupakan bagian integral pembelajaran bahasa Indonesia (BI). Kemampuan peserta didik dalam mengapresiasi sastra merupakan tuju-an utama pembelajaran sastra. Dalam Permendiknas nomor 22 tahun 2006, pembelajaran sastra bertujuan agar peserta didik mampu (1) menikmati dan 
memanfaatkan karya sastra untuk memperluas wawasan, memperhalus budi pekerti, serta meningkatkan pengetahuan dan kemampuan berbahasa, (2) menghargai dan membanggakan sastra Indonesia sebagai khazanah budaya dan intelektual manusia Indonesia (Kemendiknas, 2006).

Oemarjati (1992) berpendapat, tujuan akhir pembelajaran sastra adalah menanam dan menumbuhkembangkan kepekaan terhadap masalah-masalah manusiawi, pengenalan dan rasa hormatnya terhadap tata nilai, baik dalam konteks individual maupun sosial. Dewasa ini, rendahnya kepeka-an terhadap peristiwa-peristiwa sosial dan tata pergaulan yang mengabaikan nilainilai etika sosial, terutama di kalangan pelajar, merupakan indikasi rendahnya apresiasi siswa sekaligus gagalnya pembelajaran sastra di sekolah.

Suyitno (2012) menilai, pendidikan saat ini hanya mengedepankan penguasaan aspek keilmuan dan kecerdasan. Jika peserta didik sudah dinyatakan lulus dengan nilai akademik di atas KKM, pendidikan dianggap sudah berhasil. Pembentukan karakter dan nilai-nilai budaya bangsa di dalam diri peserta didik semakin terabaikan. Rapuhnya karakter dan nilai budaya bisa membawa kemunduran peradaban bangsa. Padahal, kehidupan masyarakat yang memiliki karakter dan budaya yang kuat akan semakin memperkuat jatidiri bangsa dan $\mathrm{Ne}-$ gara, (hlm 2). Sjamsulbachri (dalam Mae-monah, 2012: 30) menambahkan, pendidikan karakter dapat mengubah bangsa terjajah menjadi bangsa maju. Terbukti, Korea sebagai negara terjajah selama kurang lebih 30 tahun oleh Jepang, mampu bangkit menjadi negara pesaing Jepang dengan memberikan pendidikan karakter kepada bangsanya.

Karya sastra bermutu sarat de-ngan nilai spiritual, etika, dan sosial. Dalam nilai-nilai itu terkandung pesan moral sebagai pembelajaran kepada pembaca yang apresiatif untuk men-junjung nilainilai itu sebagai sikap spiritual, sosial, sekaligus mengem-bangkan wawasan pengetahuan dan keterampilan. Huck, et al (1987) dan Rothlein dan Meinbach (1991) menyatakan, bagaimanapun juga bacaan yang baik akan membuahkan pengalaman estetik bagi anak, penggunaan bahasa imajinatif dapat menghasilkan tanggapan-tanggapan intelektual dan emosional. Djuanda (2014: 196) menambahkan, pada waktu membaca, siswa belajar tentang orang lain, tentang mereka sendiri, dan kehidu-pannya. Siswa sering menemukan pe-ngalaman yang mirip dan seolah-olah dialaminya sendiri berkaitan dengan kesenangan, kesedihan, ketakutan. Di samping itu siswa juga memperoleh wawasan pada pemecahan masalah yang berkaitan dengan dunia mereka sendiri. Dengan demikian, sastra da-lam kehidupan anak bisa dijadikan pilar untuk membentuk karakter dan budi pekerti mereka.

Pendapat-pendapat di atas menekankan betapa pentingnya pembelajaran sastra dalam pembentukan karakter. Walaupun, nilai budaya dan pendidikan karakter yang disebandingkan dengan kewirausahaan, telah diperkenalkan dalam kurikulum 2006 (sering disebut KTSP), namun KTSP dinilai lebih mementingkan aspek pengetahuan, kurang mengakomodir pendidikan karakter dan pengembangan keterampilan. KTSP hanya membentuk peserta didik yang pintar, namun kurang cakap menalar dan mengimplementasikan pengetahuan dalam bersikap sehari-hari.

Basir (2014) mengatakan bahwa kurikulum 2013 (K-13), yang diang-gap sebagai penyempurnaan KTSP, menekankan pembelajaran BI sebagai sarana untuk mengembangkan kemampuan dan keterampilan menalar. 
Perubahan ini dilatarbelakangi oleh Kenyataan bahwa, kemampuan menalar peserta didik Indonesia masih sangat rendah. Hasil studi Trends in International Mathematics and Science Study (TIMSS) 2011 menyebutkan, hanya 5 persen peserta didik Indonesia mampu memecahkan persoalan yang membutuhkan pemikiran, 95 persen lainnya hanya sampai pada level menengah, yaitu memecahkan persoalan yang bersifat hapalan. Ini membuktikan, pendidikan Indonesia baru berada pada tatanan konseptual. Untuk itu, pembelajaran BI merupakan salah satu solusi, dengan menjadikannya sebagai penghela ilmu pengetahuan, hlm 230.

Sejalan dengan perlunya pendidikan karakter yang terintegrasi dalam mata pelajaran pada semua jenis dan jenjang pendidikan, maka pembelajaran sastra yang berkualitas merupakan aspek penting dalam pembentukan karakter anak bangsa. Pesanpesan karakter dalam mengapresiasi sastra terintegrasi dalam substansi karya sastra sebagai bahan ajar, dimanifestasikan dalam proses pembela-jaran, dievaluasi melalui proses dan hasil belajar. Dengan demikian, pengelolaan pembelajaran sastra merupakan faktor utama pencapaian kompetensi karakter peserta didik.

Permendikbud nomor 70 tahun 2013 menyatakan, K-13 dikembangkan dengan penyempurnaan enam pola pikir, yaitu: (1) Pola pembelajaran berpusat pada guru menjadi pembelajaran berpusat pada peserta didik, (2) pola pembelajaran satu arah menjadi pembelajaran interaktif multiarah, (3) pola pembelajaran terisolasi men-jadi pembelajaran secara jejaring, (4) pola pembelajaran pasif menjadi pembelajaran aktif-mencari, (5) pola belajar sendiri menjadi belajar kelompok, (6) pola pembelajaran alat tunggal menjadi pembelajaran berbasis multimedia (Kemendikbud, 2013).

Pola pembelajaran yang relevan dengan pola pikir (1), (2), dan (5) adalah pendekatan komunikatif (communicative approach) berbasis pembelajaran kooperatif (cooperative learning), ditunjang pendekatan sains dengan strategi penemuan (discovery learning), sesuai pola pikir (3), (4), (6).

Berdasarkan uraian di atas, maka kata kunci yang menjadi dasar pijakan penelitian ini adalah pendidikan karakter, pembelajaran sastra sebagai bagian pembelajaran BI, dan pendekatan komunikatif-kooperatif. Penelitian dilaksanakan pada semester ganjil 2017/2018, dengan subjek tindakan siswa kelas XII Busana Butik (BB) SMKN 3 Banjarbaru, berjumlah 31 siswa, semuanya perempuan.

Pertanyaan penelitian yang menjadi rumusan masalah penelitian ini adalah, bagaimanakah pelaksanaan pembelajaran sastra melalui pendekatan komunikatif berbasis kooperatif dan implikasinya terhadap pendidikan karakter siswa kelas XII BB SMKN 3 Banjarbaru? Tujuannya adalah untuk mengetahui pelaksanaan pembelajaran sastra melalui pendekatan komunikatif berbasis kooperatif dan implikasinya terhadap pendidikan karakter siswa kelas XII BB SMKN 3 Banjarbaru.

Tulisan ini diharapkan dapat digunakan sebagai referensi pembentukan karakter peserta didik melalui pembelajaran pada umumnya dan pembelajaran sastra pada khususnya. Bagi pengajar BI, tulisan ini diharapkan dapat bermanfaat sebagai alternatif pelaksanaan pembelajaran untuk meningkatkan apresiasi sastra sekaligus membina karakter siswa SMK.

\section{KERANGKA TEORI}

Dalam struktur K-13 SMK, BI termasuk kelompok mata pelajaran 
wajib, yang diberikan pada semua kelas dan semua kompetensi keahlian, dengan alokasi waktu 4 jam pelajaran per minggu. Dalam kelompok mata pelajaran wajib ini, sastra tergabung dengan mata pelajaran BI. Sastra se-cara terpisah hanya diberikan sebagai mata pelajaran peminatan akademik untuk jurusan Bahasa di SMA atau MA.

Pembelajaran satra tentu terkait dengan materi sastra. Sumardjo dan Saini (1986) menggolongkan materi sastra ke dalam dua kelompok, yakni sastra imajinatif dan sastra nonimajinatif. Sastra imajinatif terdiri dari dua genre yakni prosa dan puisi. Prosa terdiri atas fiksi dan drama. Fiksi meliputi novel, cerpen, dan novelet. Drama meliputi drama prosa dan drama puisi. Tampilan drama meliputi komedi, tragedi, melodrama, dan tragedi komedi. Puisi meliputi puisi epik, lirik, dan dramatik. Sedangkan sastra nonimajinatif terdiri dari esai, kritik, biografi, otobiografi, sejarah, memoir, catatan harian, dan surat-surat, ( hlm 13).

Materi sastra, menurut Sumardjo dan Saini (1986), cenderung ke arah sastra imajinatif atau karya sastra murni. Mereka menyebutkan tiga hal yang membedakan karya sastra (murni) dengan karya (tulis) lain yang bukan sastra. Ketiga hal itu adalah sifat khayali (fictionality), nilai-nilai seni (esthetic values), dan penggunaan bahasa yang khas (special use of language). Ketiga sifat itu tidak ditemu-kan dalam karya nonsastra, hlm 13.

Kaitannya dengan bahan ajar BI dalam K-13, proporsi bahan ajar sastra dan nonsastra terlihat pada tabel perbandingan berikut.

Tabel 1

Perbandingan Bahan Ajar Sastra dan Nonsastra dalam K-13

\begin{tabular}{ccc}
\hline Kls & $\begin{array}{c}\text { Bahan Ajar } \\
\text { Sastra }\end{array}$ & $\begin{array}{c}\text { Bahan Ajar } \\
\text { Nonsastra }\end{array}$ \\
\hline
\end{tabular}

\begin{tabular}{|c|c|c|}
\hline$X$ & 1. Teks Anekdot & $\begin{array}{l}\text { 2. Teks Ekspo- } \\
\text { sisi } \\
\text { 3. Laporan } \\
\text { Observasi } \\
\text { 4. Teks } \\
\text { Prosedur } \\
\text { Kompleks } \\
\text { 5. Teks Nego- } \\
\text { siasi }\end{array}$ \\
\hline XI & $\begin{array}{l}\text { 1. Teks Cerita } \\
\text { Pendek } \\
\text { 2. Teks Pantun } \\
\text { 3. Teks Cerita } \\
\text { Ulang } \\
\text { 4. Teks } \\
\text { Film/Drama }\end{array}$ & $\begin{array}{ll}\text { 5. } & \text { Teks } \\
\text { Eksplanasi } \\
\text { Kompleks }\end{array}$ \\
\hline XII & $\begin{array}{l}\text { 1. Teks Cerita } \\
\text { Sejarah } \\
\text { 2. Teks Novel }\end{array}$ & $\begin{array}{l}\text { 3.Teks Berita } \\
\text { 4. Teks Iklan } \\
\text { 5. Teks Edito- } \\
\text { rial/Opini }\end{array}$ \\
\hline Jlh & 7 Teks (44 \%) & 9 Teks $(56 \%)$ \\
\hline
\end{tabular}

(Sumber : Silabus Mata Pelajaran BI K-13, Kemendikbud, 2013).

Bobot bahan ajar sastra lebih sedikit dibanding bahan ajar nonsastra (44 $\%$ : $56 \%$ ). Distribusi bahan ajar ti-dak merata. Materi sastra lebih banyak diberikan di kelas XI, 4 teks, sebaliknya di kelas $X$ hanya 1 teks, sedangkan di kelas XII sebanyak 2 teks. Materi puisi hanya diwakili teks pantun di kelas XI. Bahan ajar yang terkandung dalam materi sastra lebih menekankan aspek kemampuan berbahasa daripada bersastra. Unsur-unsur karya sastra, tidak dimunculkan. Padahal unsur-unsur seperti tema, nilai, amanat, latar, watak atau karakter tokoh dalam prosa atau drama, sangat potensial untuk digali sebagai pembentuk karakter siswa. Sehingga, pendidikan karakter yang menjadi fokus utama K-13, yang diharapkan banyak pihak dapat digali melalui bahan ajar sastra, justru kontradikatif dengan sajian materi sastra yang minimalis.

Fakta ini menuai kritikan dari sejumlah kalangan. Guru-guru BI SMA yang tergabung dalam MGMP Kabu- 
paten Cirebon sampai harus berkunjung ke Badan Bahasa (15-03-17), mempertanyakan "hilangnya" sejumlah materi sastra terutama puisi dalam K-13. Kritikan tajam diungkapkan oleh Djuanda (2014) bahwa, posisi pembelajaran sastra yang dapat dijadikan pilar pembinaan karakter dan budi pekerti itu, dalam Kurikulum 2013, tidak dapat diharapkan lagi. Basir (2014: 232) menyebutkan, proporsi materi pembelajaran sastra dalam K-13 demikian meprihatinkan, (hlm 192). Rozak (2014) menyatakan bahwa sikap penyusun K13 kurang berpihak pada sastra.

Walaupun mengkritisi, Basir (2014) juga memaklumi hilangnya wajah sastra dalam K-13, karena fungsi BI sebagai penghela dan pembawa ilmu (carrier of knowledge) dalam mata pela-jaran lain. Fungsi itu mau tidak mau menuntut BI menyesuaikan diri terutama dalam aspek materi. Sastra dianggap tidak begitu menampung materi mata pelajaran lain sehingga teks yang dipelajari lebih banyak di-emban oleh bahasa, hlm 233. Sedangkan Rozak (2014), memberikan solusi agar para guru sastra, para pakar sastra, para pencinta sastra seyogyanya bekerja sama untuk menghadirkan wa-jah sastra dalam kehi-dupan bersekolah dan bermasyarakat. Kita harus mendudukan sastra pada tempat terhormat.

Menurut Effendi (1998), fase terpenting dalam pembelajaran sastra adalah penerapan. Penerapan meruakan ujung dari penikmatan. Peserta didik akan merasakan kenikmatan pengalaman pengarang melalui karya-nya, dan mencoba menerapkan nilai-nilai yang ia hayati dalam kehidupan. Penerapan itu akan menimbulkan perubahan perilaku sebagai hasil belajar, karena hakikat belajar adalah perubahan perilaku (behavior change) dari pengalaman belajarnya (lihat Berliner, 1984). Adapun perubahan perilaku oleh Suyanto (2009) diha- rapkan dapat membentuk karakter, yaitu cara ber-pikir dan berperilaku yang menjadi ciri khas tiap individu untuk hidup dan bekerja sama, baik dalam lingkup ke-luarga, masyarakat, bangsa, mau-pun negara.

Lebih lanjut, Suyitno (2012) menjelaskan pendidikan karakter tidak terpisah dengan pendidikan akademik, sehingga harus terintegrasi dengan kurikulum, dengan mengimplementasikannya dalam mata pelajaran dan keseharian peserta didik, hlm 3. Pendidikan karakter dapat diintegrasikan pada setiap mata pelajaran, sehingga materi yang berkaitan dengan norma atau nilai-nilai pada setiap mata pelajaran perlu dikembangkan, dieksplisitkan, dikaitkan dengan konteks kehidupan sehari-hari Fitri (2012) menambahkan bahwa konsep dan gagasan itu menjadikan pendidikan karakter dan budaya bangsa sebagai fokus K-13, yang dalam imple-mentasinya perlu dilakukan secara holistik, (hlm 156).

Pola pembentukan karakter tertuang dalam kompetensi dasar (KD) sebagai perilaku siswa yang harus dikondisikan di kelas. Perilaku itu meliputi kompetensi sikap spiritual (KI1), sikap sosial (KI-2), pengetahuan (KI3), dan keterampilan (KI-4). Indikator KD yang dikembangkan dalam KI-1 adalah menghayati dan menga-malkan agama yang dianutnya. Dalam KI-2 terdapat indikator jujur, disiplin, tanggung jawab, peduli (gotong royong, kerjasama, toleran, damai), santun, responsif, dan proaktif. Dalam KI-3 terdapat indikator memahami, membandingkan, menganalisis, meng-identifikasi, dan mengevaluasi. Sedangkan dalam KI-4 terdapat indikator menginterpretasi, memproduksi, menyunting, mengabstraksi, dan mengonversi (lihat Silabus BI kelas XII, Kemendikbud, 2013).

Proses pembelajaran bertumpu pada pencapaian KD dalam kelompok KI- 
3 dan KI-4, dan menjadi penentu ketercapaian KD dalam kelompok KI-1 dan KI-2. Dengan demikian, KD dalam kelompok KI-1 dan KI-2 bukan untuk diajarkan, tetapi hanya sebagai implikasi ketercapaian KD dalam KI-3 dan KI-4 (lihat Mahsun, dalam Basir, 2014: 231). Dengan demikian, proses pembelajaran harus dikelola sedemikian rupa agar kompetensi yang diharapkan dapat dicapai dengan cara memilih pendekatan dan strategi yang tepat.

Atas pertimbangan penyempurnaan pola pikir K-13, seperti telah diuraikan pada pendahuluan, maka pembelajaran sastra dalam tulisan ini menggunakan pendekatan komuni-katif berbasis pembelajaran kooperatif. Pendekatan lain sesuai pola pikir K-13, yaitu pedagogik, genre, dan sains melalui model pembelajaran penemu-an (discovery) digunakan sebagai penunjang pendekatan komunikatif - kooperatif.

Pendekatan komunikatif, menu-rut Djuanda (2008), merupakan salah satu pendekatan pembelajaran baha-sa, yang berlandaskan pada pemikiran bahwa, kemampuan menggunakan ba-hasa merupakan tujuan pembelajaran bahasa. Bahasa tidak hanya dipandang sebagai seperangkat kaidah, tetapi le-bih luas lagi, sebagai sarana untuk berkomunikasi. Bahasa ditempatkan sesuai dengan fungsinya, yaitu fungsi komunikatif. Jadi, siswa dibimbing untuk dapat menggunakan bahasa, bu-kan mengetahui tentang bahasa.

Pendekatan komunikatif mendukung efektivitas interaksi belajar-mengajar di kelas. Interaksi sebagai komunikasi pembelajaran yang diharapkan tidak hanya terjadi searah, tetapi multi-arah. Sulo dan Paranto (1985) menggambarkan pola interaksi antara guru (G) dan murid (M) sebagai berikut.

$\begin{array}{llll}\text { Pola 1: } & \mathrm{G} & \rightarrow & \mathrm{M} \\ \text { Pola 2: } & \mathrm{M} & \rightarrow & \mathrm{G} \\ \text { Pola 3: } & \mathrm{M} & \rightarrow & \mathrm{M}\end{array}$

Pola (1) merupakan pola pembelajaran tradisional. Guru lebih mendominasi kegiatan pembelajaran dengan metode ceramahnya. Sesekali siswa bertanya pada guru (pola 2). Pertanyaan siswa dijawab oleh siswa yang lain (pola 3). Pola terakhir ini sangat diharapkan dalam pembe-lajaran, karena hakikat pem-belajaran modern harus menekankan aktivitas siswa sebagai subjek didik dalam pembelajaran (students activity learning).

Pendekatan komunikatif akan lebih terdukung keterlaksanaannya dengan strategi pembelajaran kooperatif. Pembelajaran koope-ratif, menurut Isjoni (2010), adalah salah satu strategi belajar mengajar yang menekankan pada sikap atau perilaku bersama dalam bekerja atau membantu di antara sesama dalam struktur kerja sama yang teratur dalam kelompok. Keber-hasilan kerja sangat dipengaruhi oleh keterlibatan setiap anggota kelompok. Dalam pendekatan ini, siswa merupakan bagian dari sistem kerja sama dalam mencapai hasil belajar yang optimal.

Pembelajaran kooperatif juga memandang bahwa, keberhasilan belajar bukan semata-mata diperoleh dari guru, tetapi juga dari pihak lain yang terlibat dalam pembelajaran itu. Ke-berhasilan belajar dalam pendekatan ini bukan hanya ditentukan oleh kemampuan individu secara utuh, me-lainkan perolehan itu akan lebih baik jika dilakukan secara bersama-sama dalam kelompok yang terstruktur dengan baik.

Untuk mengukur keberhasilan pembelajaran dan prosesnya perlu dibuat indikator. Ada tiga aspek yang akan diukur: (1) Kualitas proses, yaitu keberhasilan tindakan melalui pendekatan komunikatif - kooperatif, (2) kualitas hasil atau produk, yaitu kemampuan siswa dalam menganalisis unsur karya sastra dan kerja kelompok, 
(3) kualitas karakter, yaitu sikap atau perilaku siswa selama proses belajar.

1. Keberhasilan tindakan melalui pendekatan komunikatif-kooperatif diukur dari tingginya aktivitas siswa, ditandai dengan pola inter-aksi yang muncul selama proses pembelajaran, yang diamati setiap lima menit. Hasil pengamatan dituangkan ke dalam format pengamatan, dihitung dan diper-sentase. Jika frekuensi pola interaksi $\mathrm{M} \rightarrow \mathrm{G}$ atau pola $\mathrm{M} \rightarrow \mathrm{M}$ lebih sering muncul dibanding pola $\mathrm{G} \rightarrow \mathrm{M}$, maka penerapan pendekatan komunikatif - kooperatif dinya-takan berhasil, proses pembelajar-an dinyatakan berkualitas.

2. Kemampuan siswa dalam menganalisis unsur karya sastra diukur dari tes kemampuan menganalisis karya sastra dan kualitas kerja kelompok. Pengukuran kualitas kerja kelompok diperlukan untuk mengetahui kemampuan dan perilaku berbahasa siswa sesuai KD (lisan maupun tulisan) dengan pende-katan komunikatif. Jika hasil tes dan kualitas kerja kelompok, siswa yang mendapat kualifikasi skor minimal baik mencapai $75 \%$ atau lebih, maka hasil belajar dalam mengana-lisis karya sastra dinyatakan ber-kualitas.

3. Kualitas karakter diukur selama proses pembelajaran, yang difokuskan pada karakter KI-1 dan KI-2 (KI-3 dan KI-4 sudah terwakili dari kua-litas hasil belajar). Karakter yang diamati sebagai indikator KI-1 adalah: (1) Berdoa sesuai ajaran agamanya sebelum dan sesudah kegiatan belajar, (2) Bersyukur atas nikmat yang diberikan Tuhan atas anugerah bahasa dan ilmu yang diperolehnya. Karakter yang dia-mati sebagai indikator KI-2 adalah: (1) jujur, (2) disiplin, (3) tanggung jawab, (4) peduli, (5) toleran, (6) san-tun, (7) responsif, dan (8) proaktif.
Pengukuran dilakukan melalui pengamatan berdasarkan frekuensi kemunculan indikator-indikator itu pada diri siswa, yang diberi bobot: 4 (amat baik) jika selalu muncul, 3 (baik) jika sering muncul, 2 (cukup) jika jarang mun-cul, dan 1 (kurang) jika tidak pernah muncul. Jika siswa yang mendapat kualifikasi skor gabungan KI-1 dan KI-2 minimal baik mencapai $75 \%$ atau lebih, maka pendidikan karakter yang terintegrasi dalam pembelajaran sastra dinyatakan berhasil.

\section{METODE PENELITIAN}

Pardjono, dkk ( 2017) berpen-dapat bahwa penelitian ini termasuk penelitian tindakan kelas (PTK), yaitu salah satu jenis penelitian tindakan yang dilakukan guru untuk mening-katkan kualitas pembelajaran (hlm. 12). Melalui penelitian ini, peneliti menga-mati peningkatan kemam-puan mengapresiasi sastra. Pengamatan itu meliputi proses, kualitas proses, dan hasil pembelajaran dengan diterapkannya pendekatan komunikatif - kooperatif, dan implikasinya terhadap pendidikan karakter. Penelitian dilakukan langsung oleh peneliti sekaligus sebagai pelaksana tindakan, bekerja sama dengan guru BI SMKN 3 Banjarbaru yang lain sebagai kolaborator/pengamat pelaksanaan tindakan.

Data penelitian dikumpulkan melalui cara trianggulasi (tes, angket, dan observasi). Tes digunakan untuk mengukur kemampuan siswa subjek dalam menganalisis kaya sastra. Tes diberikan secara tertulis dalam bentuk esay. Hasil penilaian tes dimaksudkan untuk mengukur kemampuan siswa dalam mengapresiasi karya sastra. Bahan ajar yang digunakan dalam tes adalah cuplikan novel cerita sejarah. Sehubungan dengan pendekatan dan strategi tindakan yang dipilih, dilaku- 
kan juga penilaian kemampuan komunikasi, sikap atau perilaku individu dalam kerja sama kelompok.

\section{PEMBAHASAN}

\subsection{Permasalahan Pembelajaran di Kelas XII SMK}

Kegiatan pembelajaran di kelas XII SMK selalu dihadapkan pada dilema klasik, yaitu (1) keinginan ideal untuk menuntaskan semua materi dalam kurikulum, dan (2) ambisi yang besar untuk mencapai nilai maksimal dalam UN. Keinginan pertama sering dikalahkan oleh ambisi kedua. Di SMK, selain UN, masih terdapat agenda lain, yaitu Pra-UN, USBN, dan Uji Kompetensi Keahlian (UKK). Kegiatankegiatan itu tentu dapat mengurangi beban belajar reguler, terutama di semester genap. Padahal beban belajar semester genap hanya 14 minggu per semester. Persoalan lain adalah relevansi materi ajar yang dikehendaki K-13 dengan lingkup materi (kisi-kisi) UN kurang bersesuaian. Ditambah lagi sistem penilaian, terutama UN, yang bersifat massal. UN lebih mengutamakan aspek pengetahuan. Aspek keterampilan dan sikap sering terabaikan. Hal ini berdampak pada proses pembelajaran di kelas XII.

Semua pihak tentu berharap agar semua materi ajar dalam kurikulum dapat dituntaskan dan nilai UN yang tidak mengecewakan. Langkah yang dilakukan dalam pembelajaran reguler adalah: (1) menyajikan bahan ajar sesuai lingkup materi dalam kisi-kisi UN dengan tetap berpedoman pada KD, dan (2) menggabungkan materi ajar yang relevan. Langkah pertama tentu dilakukan atas pertimbangan persiapan menghadapi UN tanpa mengabaikan target kurikulum. Sedangkan langkah kedua dilakukan atas pertimbangan waktu yang terbatas. Langkah kedua ini sangat mungkin dilaksanakan, karena
KD pada setiap bahan ajar pada dasarnya sama.

Di kelas XII hanya ada dua materi sastra, yaitu teks cerita sejarah yang diberikan pada awal semester ganjil, dan teks novel yang diberikan pada akhir semester genap. Materi teks novel sering menjadi korban, tidak sempat diajarkan, karena akhir semes-ter genap adalah waktu paling crusial, menjelang pelaksanaan UN. Sehingga, perlu dilaksanakan langkah kedua, teks cerita sejarah dan teks novel digabungkan menjadi teks novel cerita sejarah. Di Indonesia, cukup banyak cerita sejarah yang dikemas dalam bentuk novel, misalnya Gajah Mada (Langit Kresna Hariadi), Sang Pencerah (Ahmad Nasery Basral), Sang Patriot (Irma Devita), Sang Penumpas (Dukut IW), Rembulan Ungu (Bondan Nusan-tara), dan lain-lain.

Urutan materi mengacu pada KD dalam kelompok KI-3 dan KI-4 dengan pendalaman materi pada kompetensi membandingkan teks, menganalisis teks, menginterpretasi makna teks, mengevaluasi teks, dan mengabstraksi teks. Pendalaman materi dilakukan sesuai kajian struktural sastra, karena terkait dengan lingkup materi UN yang banyak menggunakan teori struktural, seperti terlihat pada tabel berikut.

Tabel 2

Pendalaman Materi Sastra dalam Lingkup Materi UN (Kisi-kisi)

\begin{tabular}{|c|c|c|}
\hline No & KD & Lingkup Materi UN \\
\hline 1. & $\begin{array}{l}\text { Memban- } \\
\text { dingkan } \\
\text { teks }\end{array}$ & $\begin{array}{l}\text { - membandingkan } \\
\text { pola karya sastra } \\
\text { (berdasarkan gaya, } \\
\text { tema, unsur). }\end{array}$ \\
\hline 2. & $\begin{array}{l}\text { Menganal } \\
\text { i-sis teks }\end{array}$ & $\begin{array}{l}\text { - } \text { mengidentifikasi } \\
\text { unsur karya sastra; } \\
\text { - menganalisis } \\
\text { hubungan } \\
\text { antarunsur; } \\
\text { - menentukan bukti } \\
\text { watak, setting; } \\
\text { - mengaitkan isi }\end{array}$ \\
\hline
\end{tabular}




\begin{tabular}{|c|c|c|}
\hline & & $\begin{array}{l}\text { dengan kehidupan } \\
\text { saat ini. }\end{array}$ \\
\hline 3. & $\begin{array}{l}\text { Menginte } \\
\text { r-pretasi } \\
\text { makna } \\
\text { teks }\end{array}$ & $\begin{array}{l}\text { - menentukan kata } \\
\text { yang } \\
\text { bermakna/majas/ } \\
\text { kias dalam karya } \\
\text { sastra. }\end{array}$ \\
\hline 4. & $\begin{array}{l}\text { Mengeva- } \\
\text { luasi teks }\end{array}$ & $\begin{array}{l}\text { menilai keung- } \\
\text { gulan/kelemah } \\
\text { an karya sastra. }\end{array}$ \\
\hline 5. & $\begin{array}{l}\text { Mengab- } \\
\text { straksi } \\
\text { teks }\end{array}$ & $\begin{array}{l}\text { - menyimpulkan } \\
\text { isi tersirat } \\
\text { dalam karya } \\
\text { sastra; } \\
\text { - meringkas isi } \\
\text { karya sastra. }\end{array}$ \\
\hline
\end{tabular}

(Sumber : Kisi-kisi UN 2017/2018)

\subsection{Pelaksanaan Pratindakan}

Pratindakan adalah kegiatan awal sebelum pembelajaran, bertujuan untuk mengetahui kemampuan siswa dalam menganalisis unsur karya sastra melalui tes, dan untuk mengetahui tingkat apresiasi sastra siswa melalui angket. Dari hasil tes pratindakan diketahui rerata nilai yang dicapai siswa 46,61 atau D (kurang). Kualifikasi nilai terbanyak ada-lah E (amat kurang), yaitu 61,29 $\%$. Nilai D dicapai oleh 22,58 \%. Sedangkan nilai C (cukup) diperoleh sebanyak $16,13 \%$ siswa. Tak seorang pun siswa subjek mencapai kualifikasi nilai B (baik), apalagi A (amat baik). Ini berarti, sebagian besar siswa subjek tidak mampu menganalisis karya sastra dengan baik.

Hasil angket mengindikasikan rendahnya apresiasi siswa terhadap karya sastra. Hal ini terlihat dari frekuensi kegi-atan membaca karya sastra. Hanya 41,94 \% siswa yang menyatakan sering membaca karya sastra. Di samping itu, hanya 38,71 \% siswa yang mengaku karya sastra yang dibaca itu dapat menyentuh perasaannya.

Dari aspek pembelajaran, siswa yang mengaku pernah mempelajari unsur karya sastra sebanyak 98,32\%. Namun, sebagian besar $(90,32 \%)$ tidak memahami nilai dan pesan moral yang terkandung dalam karya sastra. Sehingga, sebagian besar siswa $(51,61 \%)$ mengaku pesan moral yang terkandung dalam karya sastra tu tidak memengaruhi perilakunya. Rata-rata siswa $(80,65 \%)$ menyukai pelajaran sastra. Namun, hanya 19,35 $\%$ yang menyukai karya sastra. Hal ini disebabkan rendahnya frekuensi pemberian tugas oleh guru untuk menganalisis karya sastra, baik secara individual maupun kelompok $(6,45 \%$ dan 9,68 \%), dan terbatasnya buku-buku karya sastra yang tersedia di perpustakaan sekolah, sebagaimana diakui oleh $67,74 \%$ siswa sampel.

\subsection{Pelaksanaan Tindakan}

Pembelajaran sastra untuk materi pokok Teks Novel Cerita Sejarah dilaksanakan dalam dua siklus. Tiap siklus terdiri atas tiga kali pertemuan tatap muka (PTM), meliputi kegiatan awal, kegiatan inti, dan kegiatan akhir. Sebelumnya melalui model discovery, guru meminta siswa untuk mencari referensi bahan ajar dari berbagai sumber termasuk internet untuk dibahas dalam kegiatan inti. Pada kegiatan inti PTM perta-ma, guru memandu siswa mendiskusikan teori unsur karya sastra yang diperolehnya melalui berbagai sumber sekaligus membahas soal tes pratindakan hingga berakhirnya PTM pertama siklus I.

Pada PTM kedua, guru membagikan cuplikan novel Sang Pencerah (A. Nasery B.). Setelah menerangkan sinopsis cerita, guru 
meminta siswa membentuk kelom-pok yang terdiri atas 5 - 6 anggota untuk membahas unsur karya sastra, yaitu tema, majas, dan setting yang terkandung dalam teks itu. Di akhir PTM kedua, siswa diminta memper-siapkan laporan hasil kerja kelompok untuk dibahas dalam diskusi kelas pada PTM ketiga. Pada PTM ketiga, siswa melakukan presentasi hasil kerja kelompok untuk dibahas oleh kelompok lain. Masingmasing kelompok diberi kesempatan yang sama untuk memresentasikan dan membahas hasil kerja kelompok. Guru memberikan arahan, pelurusan, atau simpulan setiap selesai pembahasan sesi kelompok. Di akhir PTM ketiga siklus I, guru melakukan tes.

Pada tindakan siklus II, pola pembelajaran dan langkah-langkahnya lebih kurang sama dengan tindakan siklus I. Perbedaannya terletak pada nilai intrinsik dan cuplikan novel yang dibahas. Pada siklus II nilai instrinsik yang dibahas adalah watak, nilai, dan amanat atau pesan moral yang terkandung dalam cuplikan teks novel Rembulan Ungu (Bondan N.).

\subsubsection{Kualitas Proses Belajar}

Pendekatan komunikatif ber-basis kooperatif yang diterapkan pada pembelajaran sastra ternyata berhasil meningkatkan intensitas komunikasi dan interaksi belajar mengajar di kelas. Hasil pengamatan pada kedua siklus mengindikasikan terjadinya peningkatan proses pembelajaran, ditandai dengan komunikasi yang terjalin baik di antara para siswa.

Pada tindakan siklus I, pola interaksi $\mathrm{G} \rightarrow \mathrm{M}$ secara bertahap berhasil dikurangi dari $66,67 \%$ pada PTM pertama menjadi $33,33 \%$ dan $16,67 \%$ pada PTM kedua dan ketiga. Hal ini sekaligus meningkatkan pola $\mathrm{M} \rightarrow \mathrm{G}$ pada PTM ketiga menjadi $27,78 \%$, setelah sebelumnya hanya $22,22 \%$ pada PTM pertama dan kedua. Pola $\mathrm{M} \rightarrow \mathrm{M}$ menunjukkan peningkatan yang berarti dari $11,11 \%$ pada PTM pertama menjadi $44,45 \%$ dan $55,55 \%$ pada PTM kedua dan ketiga. Dengan demikian, telah terjadi peningkatan aktivitas siswa yang cukup signifikan. Namun demikian, dominasi guru dalam proses pembelajaran masih tinggi. Hal ini diketahui dari rata-rata pola $\mathrm{G} \rightarrow \mathrm{M}$ sebesar $39 \%$, dibanding pola $M \rightarrow G$ atau pola $\mathrm{M} \rightarrow \mathrm{M}$, masing-masing sebesar 24 $\%$ dan $37 \%$ (persentase dibulatkan).

Pada siklus II, guru mengurangi intensitas komunikasinya, sehingga pola $\mathrm{G} \rightarrow \mathrm{M}$ menunjukkan tren menurun dari $27,78 \%$ pada PTM pertama dan kedua menjadi $16,67 \%$ pada PTM ketiga. Demikian juga pola $\mathrm{M} \rightarrow \mathrm{G}$ mengalami penurunan dari $38,89 \%$ pada PTM pertama menjadi 33,33 \% dan 22,22\% pada PTM kedua dan ketiga. Yang cukup menggembirakan adalah terjadinya peningkatan komunikasi pola $\mathrm{M}$ $\rightarrow \mathrm{M}$ dari $33,33 \%$ pada PTM pertama menjadi $38,89 \%$ dan $61,11 \%$ pada PTM kedua dan ketiga. Ini berarti, pada tindakan siklus II, pendekatan komunikatif - kooperatif menunjukkan tingkat keberhasilan proses yang lebih baik dibanding siklus I. Pada tindakan siklus II ini, guru berhasil menekan intensitas pola $\mathrm{G} \rightarrow \mathrm{M}$ dari $39 \%$ pada siklus I menjadi $24 \%$, sekaligus meningkatkan pola $\mathrm{M} \rightarrow \mathrm{G}$ dari $24 \%$ pada siklus I menjadi $31 \%$, dan pola $\mathrm{M} \rightarrow \mathrm{M}$ dari 37 $\%$ pada siklus I menjadi $45 \%$. Penurunan pola $G \rightarrow M$ dan peningkatan pola $M \rightarrow G$ dan $M \rightarrow M$ dibanding tindakan sebelumnya menunjukkan tren positif keberhasilan proses pembelajaran. Lihat tabel dan grafik berikut. 
Perbandingan Aktivitas

Komunikasi/Interaksi Belajar mengajar pada Proses Pembelajaran Sastra

\begin{tabular}{ccccc}
\hline No. & Pola & S- I & S-II & Tren \\
\hline 1. & $\mathrm{G} \rightarrow \mathrm{M}$ & $39 \%$ & $24 \%$ & Positif \\
\hline 2. & $\mathrm{M} \rightarrow \mathrm{G}$ & $24 \%$ & $31 \%$ & Positif \\
\hline 3. & $\mathrm{M} \rightarrow \mathrm{M}$ & $37 \%$ & $45 \%$ & Positif \\
\hline
\end{tabular}

(Sumber : Hasil Pengamatan).

Grafik 1

Perbandingan Aktivitas

Komunikasi/Interaksi

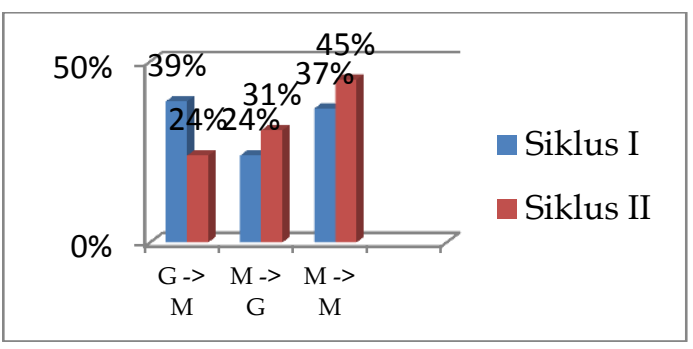

\subsubsection{Kualitas Hasil Belajar}

Kualitas hasil belajar diukur dari aktivitas siswa dalam kerja kelompok dan tes kemampuan menganalisis karya sastra. Aktivitas kerja kelompok dinilai secara individual dengan mengamati aktivitas individu dalam kelompok, perilaku atau sikap dalam berdiskusi, dan kemampuan berpendapat secara argumen-tatif.

Evaluasi aktivitas kerja kelompok pada tindakan siklus I menunjukkan, rata-rata skor aktivitas kerja kelompok adalah 41,23 (B). Kualifikasi nilai terbanyak adalah $\mathrm{B}$ dan $\mathrm{C}$, masing-masing $32,26 \%$ siswa. Kualifikasi A dicapai oleh 22,58 \% siswa. Sedangkan kualifikasi D dicapai oleh 12,90 \% siswa. Pada tindakan siklus II, skor rata-rata aktivitas kerja kelompok adalah 42,81 (B). Kualifikasi terbanyak adalah A, sebanyak 38,71 \%. Terbanyak kedua adalah B, 29,03 \%. Nilai C dan D berada pada urutan ketiga dan keempat, masing-masing 25,81 \% dan 6,45\%. Pada kedus siklus tidak ditemukan siswa subjek yang mendapat skor E. Ini berarti, aktivitas kerja kelompok mela- lui pendekatan komunikatif-kooperatif dalam pembelajaran sastra menunjukkan kinerja yang baik.

Skor rerata aktivitas kerja kelompok pada tindakan siklus II mengalami peningkatan sebesar 1,58 poin dibanding siklus I. Perbandingan skor terlihat pada tabel berikut.

Tabel 4

Perbandingan Distribusi Frekuensi Aktivitas Kerja Kelompok

Pembelajaran Komunikatif/Kolaboratif antara Siklus I dengan Siklus II

\begin{tabular}{|c|c|c|c|c|c|}
\hline \multirow[t]{2}{*}{ Rentang } & \multirow[t]{2}{*}{$Q$} & \multicolumn{2}{|c|}{ Siklus I } & \multicolumn{2}{|c|}{ Siklus II } \\
\hline & & f & $\%$ & $f$ & $\%$ \\
\hline \multirow[t]{2}{*}{$46-50$} & A & 7 & 22,5 & 12 & 38,71 \\
\hline & & & 8 & & \\
\hline \multirow[t]{2}{*}{$41-45$} & B & 10 & 32,2 & 9 & 29,03 \\
\hline & & & 6 & & \\
\hline \multirow{2}{*}{$36-40$} & C & 10 & 32,2 & 8 & 25,81 \\
\hline & & & 6 & & \\
\hline \multirow[t]{2}{*}{$31-35$} & $\mathrm{D}$ & 4 & 12,9 & 2 & 6,45 \\
\hline & & & 0 & & \\
\hline$\leq 30$ & $E$ & 0 & 0,00 & 0 & 0,00 \\
\hline Jlh & & 31 & 100 & 31 & 100 \\
\hline
\end{tabular}

(Sumber: Hasil Pengamatan).

Peningkatan kualifikasi nilai A pada siklus II berpengaruh pada penurunan kualifikasi nilai di bawahnya. Kualifikasi nilai D pada penilaian siklus I yang tadinya sebanyak 12,90\% berkurang menjadi $6,45 \%$ pada penilaian siklus II. Demikian pula kualifikasi nilai C dan B, pada tindakan siklus I sebanyak 32,26 \% berkurang menjadi $25,81 \%$ dan 29,03 \%. Lihat Grafik berikut. 
Grafik 2

Perbandingan Distribusi Frekuensi Aktivitas Kerja Kelompok

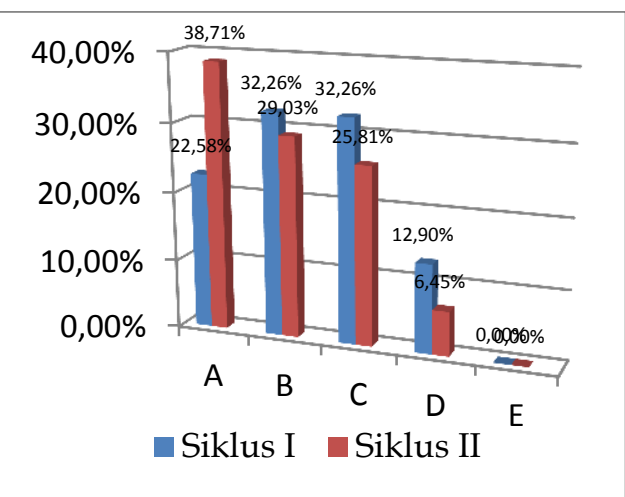

Kemampuan siswa dalam menganalisis karya sastra melalui tes di akhir PTM siklus I menunjukkan capaian kualifikasi nilai A dan B, masingmasing sebanyak $48,39 \%$ dan $51,61 \%$. Fakta ini mengindikasikan, kemampuan siswa dalam mengapresiasi sastra setelah diberikan tindakan meningkat signifikan.

Pada siklus II, kemampuan siswa juga menunjukkan peningkatan dibanding hasil tes pada siklus I. Siswa yang mencapai kualifikasi nilai A sebanyak $61,29 \%$ dan B sebanyak 38,71 \%. Tidak ada siswa subjek yang mendapat nilai di bawahnya. Rata-rata nilai yang dicapai oleh siswa adalah 76,81. Angka rata-rata ini mengalami peningkatan dibanding hasil tes kemampuan pada siklus I, yakni sebesar 74,81. Perbandingan capaian kemampuan siswa subjek dalam tiga kali pelaksanaan tes tergambar pada tabel dan grafik berikut.

Tabel 5

Perbandingan Hasil Tes Kemampuan Menganalisis Karya Sastra

\begin{tabular}{lccccccc}
\hline Renta & Q & \multicolumn{2}{c}{ PT } & \multicolumn{2}{c}{ S- I } & \multicolumn{2}{c}{ S- II } \\
\cline { 3 - 8 } ng & & f & $\%$ & f & $\%$ & F & $\%$ \\
\hline $76-$ & A & 0 & 0 & 1 & 48, & 1 & 61, \\
100 & & & & 5 & 4 & 9 & 3 \\
\hline $66-75$ & B & 0 & 0,0 & 1 & 51, & 1 & 38, \\
& & & & 6 & 6 & 2 & 7 \\
\hline $56-65$ & C & 5 & 16, & 0 & 0 & 0 & 0, \\
& & & 1 & & & & 0 \\
\hline $46-55$ & D & 7 & 22, & 0 & 0 & 0 & 0 \\
& & & 9 & & & & \\
\hline
\end{tabular}

\begin{tabular}{cccccccc}
\hline$\leq 45$ & E & 1 & 61, & 0 & 0 & 0 & 0 \\
& 9 & 3 & & & & \\
\hline Jumlah & $\mathbf{3}$ & $\mathbf{1 0 0}$ & $\mathbf{3}$ & $\mathbf{1 0 0}$ & $\mathbf{3}$ & $\mathbf{1}$ \\
& $\mathbf{1}$ & & $\mathbf{1}$ & & $\mathbf{1}$ & $\mathbf{0}$ \\
& & & & & & $\mathbf{0}$ \\
\hline
\end{tabular}

(Sumber : Hasil Tes).

Grafik 3

Perbandingan Hasil Tes Kemampuan Menganalisis Karya Sastra

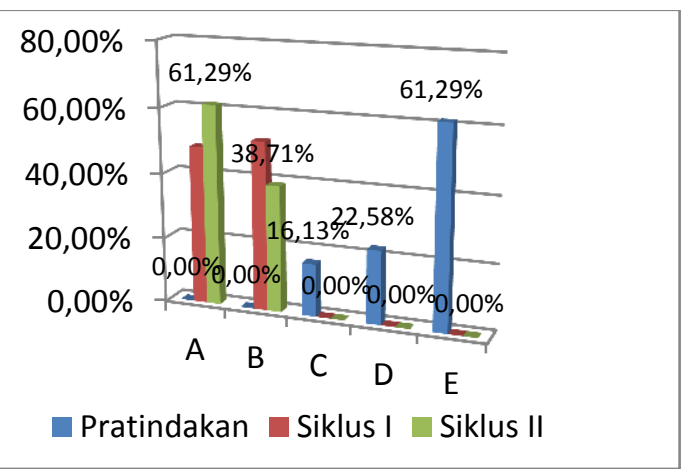

Pengamatan terhadap proses pembelajaran sastra dengan pendekatan komunikatif - kooperatif menunjukkan peningkatan kualitas pembelajaran yang signifikan. Seluruh kegiatan pembelajaran menggambarkan aktivitas siswa yang tinggi. Hal ini sesuai dengan hakikat pembelajaran yang lebih terpusat pada siswa.

Keberhasilan hasil belajar dike-tahui dari hasil tes pascatindakan. Pada pelaksanaan tindakan siklus II, hasil tes kemampuan siswa dalam menganalisis karya sastra mengalami peningkatan signifikan dibanding hasil tes pratindakan dan tindakan siklus I. Peningkatan itu diketahui setelah melihat perbandingan hasil tes pratindakan, tindakan siklus I dan siklus II sebagaimana tersaji dalam tabel 5 dan grafik 3 . Dengan demikian, pendekatan komunikatif-kooperatif terbukti mampu meningkatkan kualitas produk dan kualitas proses pembelajaran sastra.

\subsubsection{Kualitas Karakter}

Kualitas karakter diukur dari pengamatan terhadap sikap/peri-laku 
peserta didik selama proses belajar pada setiap PTM. Melalui pendekatan komunikatif-kooperatif, karakter siswa lebih mudah diamati ketika berdiskusi. Hasil pengamatan diberi bobot menjadi skor karakter.

Pencapaian kualitas karakter, sesuai indikator pencapaian kompetensi, diukur dari persentase skor gabungan sikap spiritual dan sikap sosial yang dicapai siswa subjek.

Rerata skor karakter yang dicapai siswa subjek berikut dan pada setiap PTM masing-masing siklus dapat dilihat pada tabel dan grafik berikut. Tabel 6

Capaian Skor Rata-rata Hasil Pengamatan Karakter Sikap/Perilaku

Setiap PTM pada Siklus I dan II
Tabel dan grafik di atas menunjukkan, pada siklus I PTM pertama, skor gabungan mencapai rerata 31,22 (B), PTM kedua 31,29 (B), dan PTM ketiga 31,87 (B). Skor gabungan yang dicapai siswa pada tiap PTM berkualifikasi B (baik) dan C (cukup). pada siklus II, rerata skor gabungan pada PTM pertama 31,84 (B), PTM kedua 32,35 (B), dan PTM ketiga 33,81 (B).

Pada siklus I PTM kesatu dan kedua, siswa yang mendapat skor B 64,52 $\%$, skor C 35,48 \%. Sedangkan pada PTM ketiga, skor B 70,97 \%, skor C 29,03\%. Sedangkan pada siklus II PTM pertama, siswa yang mendapat skor B 74,19 \%, skor C 25,81 \%. Pada PTM kedua, skor B $87,10 \%$, skor C $12,90 \%$. Pada PTM ketiga, skor B 93,55 \%, skor C 6,45\%.

\begin{tabular}{cccccccc}
\hline $\mathbf{N}$ & Kark- & \multicolumn{3}{c}{ Siklus I/PTM ke- } & \multicolumn{3}{c}{ Siklus II/PTM } \\
\cline { 3 - 8 } o & ter & $\mathbf{1}$ & $\mathbf{2}$ & $\mathbf{3}$ & $\mathbf{1}$ & $\mathbf{2}$ & 3 \\
\hline 1. & Spiri- & 6,26 & 6,39 & 6,64 & 6,48 & 6,77 & 7, \\
& tual & & & & & & 0 \\
\hline 2. & Sosial & 24,9 & 25,0 & 25,2 & 25,3 & 25,6 & 27 \\
& & 7 & 6 & 2 & 2 & 1 & 1 \\
\hline 3. & Spiri- & $\mathbf{3 1 , 2}$ & $\mathbf{3 1 , 2}$ & $\mathbf{3 1 , 8}$ & $\mathbf{3 1 , 8}$ & $\mathbf{3 2 , 3}$ & $\mathbf{3}$ \\
& tual/ & $\mathbf{2}$ & $\mathbf{9}$ & $\mathbf{7}$ & $\mathbf{4}$ & $\mathbf{5}$ & $\mathbf{8}$ \\
& Sosi- & & & & & &
\end{tabular}
al

(Sumber : Hasil Pengamatan).

Perbandingan capaian rerata hasil pengamatan karakter gabu-ngan sikap spiriuial dan sikap sosial setiap PTM pada siklus I dan II dapat dilihat pada grafik berikut.

\section{Grafik 4}

Perbandingan Capaian Rata-rata Hasil

Pengamatan Karakter Gabungan Sikap Spiritual dan Sikap Sosial Setiap PTM pada Siklus I dan II

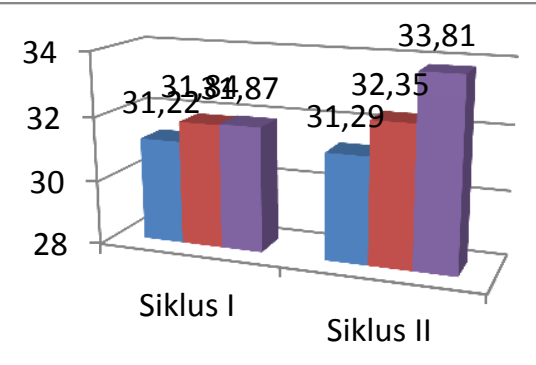

PTM Kesatu — PTM Kedua — PTM Ketiga kualifikasi skor B yang dicapai 7,(\$iswa dari PTM pertama - ketiga siklus 0I hingga PTM pertama siklus II masih ${ }_{13}^{27}$ di bawah angka $75 \%$. Kualifikasi skor B 33lebih dari $75 \%$ baru dicapai siswa pada ${ }^{81}$ PTM kedua dan ketiga siklus II. Ini berarti, sesuai indikator pencapaian kompetensi yang telah ditetapkan, pendidikan karakter yang terintegrasi dalam pembelajaran sastra baru dinyatakan berhasil pada PTM kedua dan ketiga siklus II.

\subsection{Implikasi Pembelajaran dan Materi Sastra terhadap Karakter}

Pritchard (1988: 467) menya-takan, karakter adalah sesuatu yang berkaitan dengan kebiasaan hidup individu yang bersifat menetap dan cenderung positif, sesuatu yang telah menjadi kebiasaan agak sulit berubah. Pendapat ini sejalan dengan fakta yang ditunjukkan dalam grafik 4, rerata capaian skor gabungan setiap PTM pada siklus I tidak mengalami peningkatan berarti. Peningkatan berarti baru terjadi pada tindakan siklus II dengan adanya penambahan kualifikasi skor B yang mencapai lebih dari $75 \%$ siswa, dibanding siklus I yang kurang dari $75 \%$. Fakta 
ini sesuai pendapat Haryati (2014) bahwa, pembelajaran dalam K-13 harus mengembangkan kompetensi karakter dengan lintasan perolehan yang bertahap, yang sarat dengan pendidikan kesabaran.

K-13 secara tegas menekankan aspek pendidikan karakter dilaksanakan secara holistik, sehingga harus diintegrasikan ke dalam mata pelajaran. Ini berarti, ada dua faktor penting yang menentukan terbentuknya karakter peserta didik yang terintegrasi dalam pembelajaran sastra, yaitu proses dan materi ajar.

\subsubsection{Implikasi Proses Pembelajaran terhadap Pembentukan Karakter}

Proses pembelajaran berperan penting dalam pencapaian kompetensi peserta didik. Pembelajaran sastra yang bersifat teoritis harus diubah dengan banyak mengajarkan praktik mengapresiasi. Hal ini sesuai dengan hakikat pembelajaran sastra sebagai pembelajaran apresiasi. Apresiasi sastra, menurut Effendi (1998), adalah kegiatan mengakrabi karya sastra secara sungguh-sungguh. Di dalam kegiatan mengakrabi terjadi proses pengenalan, pemahaman, penghayatan, penikmatan, setelah itu penerapan, hal (hlm 26)

Dengan demikian, pembelajaran sastra tidak sebatas pada penyampaian teori belaka. Teori-teori sastra hanya memberikan wawasan kognitif bagi siswa, yang terpantau dari hasil ujian. Asmani (2011) menyimpulkan, proses pendidikan sekarang terlalu mementingkan aspek kognitif dan mengabaikan kreativitas. Pembelajaran sastra, di samping mem-berikan bekal kognitif, juga harus dapat menumbuhkan sikap dan perilaku agar siswa memiliki kepekaan sosial (afektif), sesuai dengan amanat yang disampaikan dalam karya sastra, (hlm 37).

Permendikbud nomor 103 tahun 2014 menegaskan, pembelajaran dila- ksanakan berbasis aktivitas dengan karakteristik menyenangkan, menantang, dan memotivasi peserta didik berpartisipasi aktif (Kemendikbud, 2014). Pembelajaran harus terpusat pada siswa. Kenyataan sebaliknya banyak terjadi; guru lebih endo-minasi pembelajaran. Dari hasil penelitian Santiningtyas (2012) terungkap, sebagian besar model pembelajaran yang digunakan dalam RPP cenderung berpusat pada guru. Padahal lingkungan dan sumber belajar lain sangat memungkinkan untuk difasilitasi agar siswa lebih aktif.

Pendekatan komunikatif berbasis kooperatif bertujuan mengurangi dominasi guru, agar siswa lebih berpartisipasi dalam pembelajaran. Hasil angket pascatindakan sebagai salah satu fakta penelitian ini menyimpulkan, sebagian besar siswa tidak menyukai pembelajaran yang terlalu banyak ceramah. Penerapan pende-katan komunikatif - kooperatif dalam pembelajaran sastra dilakukan dengan memperbanyak komunikasi antarsiswa melalui diskusi kelompok dan diskusi kelas. Dengan pola ini, siswa dituntut lebih banyak menggali dan memecahkan permasalahan sendiri (inquiry). Keberhasilan proses pembelajaran diukur dari frekuensi munculnya interaksi komunikasi $\mathrm{M} \rightarrow \mathrm{M}$ atau $\mathrm{M} \rightarrow \mathrm{G}$ lebih banyak daripada pola komunikasi $\mathrm{G} \rightarrow \mathrm{M}$ (Sulo dan Paranto, 1985).

Pendekatan komunikatif-kooperatif serta merta dapat mengondisikan sikap atau perilaku siswa di kelas untuk men-capai kompetensi karakter, terutama KI-2. Melalui kegiatan diskusi, siswa dapat menunjukkan perilaku jujur, santun, responsif, dan proaktif dalam menyampaikan gagasan (lisan) sebagai solusi yang dia yakini kebenarannya. Melalui kerja kelompok, siswa dapat menunjukkan perilaku disiplin, tanggung jawab, peduli (gotong royong, kerja sama, dan toleran) 
dalam melaksanakan tugas-tugas kelompok yang diberikan guru.

\subsubsection{Implikasi Materi Sastra Terhadap Pembentukan Karakter}

Rendahnya apresiasi sastra siswa merupakan hal yang perlu dibenahi dalam pembelajaran sastra. Penyebabnya, sesuai hasil angket, adalah (1) sedikitnya tugas-tugas yang diberikan guru dalam menganalisis karya sastra, baik secara individual maupun kelompok, dan (2) minimnya bacaan sastra di perpustakaan sekolah. Fakta ini mengisyaratkan agar tugas menganalisis karya sastra perlu ditingkatkan, dan perpustakaan perlu ditambah koleksinya dengan karya sastra bermutu.

Kegiatan menganalisis karya sastra dalam pembelajaran sastra merupakan upaya nyata untuk meningkatkan apresiasi sastra dan membentuk karakter siswa. Kegiatan ini hanya bisa dilakukan dengan cara membaca, mempelajari, dan memahami substansi karya sastra yang akan dianalisis. Keterbatasan materi merupakan persoalan serius dalam pembelajaran sastra. Syafrial (2014: 72) menyatakan, K-13 melakukan reduksi besar-besaran ter-kait dengan jenis teks sastra. Dari sejumlah kekayaan yang ada dalam khazanah sastra Indonesia, hanya seba-gian kecil yang dimasukkan dalam kurikulum. Bahkan, perlu juga diper-tanyakan, apakah materi sastra yang disajikan dalam K-13 dapat memenuhi tujuan pembelajaran sas-tra(?).

Substansi nilai pendidikan dalam sebuah karya sastra sangat esensial, karena berkaitan langsung dengan penanaman karakter. Keberadaan materi sastra dalam K-13 perlu menjadi perhatian agar sesuai tujuan pengajaran sastra, tetapi tidak harus dijadikan alasan untuk tidak dapat meningkatkan apresiasi sastra sebagai salah satu pilar pembentukan karakter siswa. Rozak (2014: 2) menyarankan, kita tidak mungkin mengubah struktur K-13, yang diperlukan adalah cara menyiasati agar materi sastra dapat berkontribusi terhadap pemilikan karakter siswa. Cara yang pasti bisa dilakukan adalah memperkaya dan memilih bahan ajar yang secara langsung bisa membentuk karakter siswa.

Pada siklus I, untuk memahami unsur tema, majas, dan setting dalam teks cerita sejarah digunakan cuplikan no-vel Sang Pencerah karya A. Nasery B. sebagai bahan ajar. Novel ini mengisahkan perjuangan Ahmad Dahlan membangun organisasi Muhammadiyah dan cita-cita perjuangan pergerakan nasional. Tema perjuangan (patriotime) tokoh menjadi unsur pembangun karakter dalam materi ini. Kegigihannya memerangi kebodohan dan keterbelakangan bangsanya sendiri melalui kegiatan dakwah dan pendidikan, dan perjuangannya untuk membangun persatuan nasional bersama tokoh lainnya merupakan sikap yang diharapkan dapat diteladani siswa. Materi majas dan setting dimaksudkan untuk mengantarkan siswa memahami makna teks novel yang dianalisis. Melalui materi majas, siswa dibimbing untuk memahami kehalusan bahasa, sehingga bisa digunakannya dalam bertutur dan bertindak. Melalui materi setting, siswa diharapkan dapat memiliki wawasan tentang tempat dan waktu kejadian sebuah peristiwa bersejarah.

Pada siklus II, bahan ajar yang digunakan adalah cuplikan novel Rembulan Ungu karya Bondan Nusantara untuk memahami watak, nilai, dan amanat atau pesan moral dalam teks. Novel ini mengisahkan konflik di kerajaan Mataram pada abad ke-16, di masa pemerintahan Sunan Amangkurat I, penerus Sultan Agung. Watak atau karakter dalam cerita digambarkan secara lengkap melalui tokoh antagonis (Sunan Amangkurat), yang dzalim, serakah, 
penjilat penjajah kontra tokoh protagonis (Panjalu, prajurit Mataram), yang berani, jujur, lembut tapi tegas. Tokoh netral (Adipati Anom, sang putra mahkota) terjepit di tengah-tengah, karena wataknya yang kaku, plin-plan, dan tak punya pendirian, sehingga tak bisa mengambil putusan di saat kerajaan dalam keadaan genting; apakah berpihak pada ayahandanya atau pada pejuang kebenaran.

Wardaya dan Schlossberg (dalam Nusantara, 2011) menilai, novel ini penuh dengan nilai kemanusiaan, keadilan, dan kesetaraan, pesan moral yang terkandung di dalamnya sangat relevan untuk direnungkan oleh para penguasa dan generasi muda pada abad modern. Sehingga cocok dijadikan sebagai bahan ajar pembentukan karakter siswa.

\section{PENUTUP}

\subsection{Simpulan}

Berdasarkan uraian yang telah dipaparkan dapat disimpulkan hal-hal sebagai berikut:

1. Apresiasi sastra siswa masih sangat rendah. Hal ini disebabkan, proses pembelajaran yang kurang memotivasi siswa untuk belajar sastra, di samping minimnya tugas-tugas yang diberikan guru untuk membaca dan menganalisis karya sastra, dan terbatasnya koleksi buku-buku sastra di perpusta-kaan sekolah.

2. Berbagai kajian empirik menyimpulkan, kegagalan pembelajaran sastra lebih banyak disebabkan pola dan strategi pembelajaran yang kurang memberikan kesempatan kepada siswa untuk beraktivitas, sebagai dampak dari dominasi guru dalam proses pembelajaran.

3. Pendekatan komunikatif berbasis kooperatif dalam pembelajaran sastra merupakan pilihan yang tepat, karena pendekatan dan strategi ini bisa diterapkan melalui teknik diskusi yang dapat mengembang-kan wawasan dan kreativitas siswa dalam berbahasa, sekaligus dapat mengondisikan karakter sikap sosial sesuai kehendak K-13.

4. Pendekatan komunikatif berba-sis kooperatif dalam pem-belajaran sastra menunjukkan kualitas proses, kualitas hasil, dan kualitas karakter. Kualitas proses ditandai dengan meningkatnya aktivitas siswa dalam interaksi belajar menga-jar dengan frekuensi pola $\mathrm{M} \rightarrow \mathrm{G}$ dan $\mathrm{M} \rightarrow \mathrm{M}$ yang lebih baik daripada pola $G \rightarrow$ M. Kualitas hasil ditandai dengan meningkatnya kemampuan siswa dalam menganalisis karya sastra dan kerja kelompok. Kualitas karakter ditan-ai dengan meningkatnya capaian skor sikap spiritual dan sikap sosial pada siklus II dibanding siklus I.

\subsection{Saran}

Sebagai penutup tulisan ini dikemukakan saran/rekomendasi sebagai berikut:

1. Pendidikan karakter yang dibangun secara holistik memerlukan sinergitas antara kualitas pembelajaran dan pemilihan materi yang tepat. Guru sebagai disainer pembelajaran harus dapat menentukan pendekatan dan strategi yang tepat serta mengembangkan bahan ajar yang relevan dengan pembentukan karakter peserta didik.

2. Sebagai pembelajaran apresiasi, pembelajaran sastra harus lebih ditekankan pada praktik mengapresiasi sastra yang sebenarnya bukan penyajian teori tentang sastra. Kegiatan mengapresiasi karya sastra sangat potensial untuk menggali nilai-nilai dan pesan moral yang terkandung di dalamnya, sebagai pembentuk karakter dan budi pekerti siswa. 
3. Keterbatasan bahan ajar sastra dalam K-13 bukan merupakan alasan untuk tidak dapat meningkatkan apresiasi sastra siswa sebagai wahana pembentukan karakter. Cara yang pasti bisa dilakukan adalah memerkaya dan memilih materi ajar yang secara langsung dapat membentuk karakter siswa melalui penggalian nilai dan pesan moral karya sastra.

4. Pembentukan karakter melalui apresiasi sastra tidak semata-mata bergantung pada proses pembelajaran, tetapi juga bisa dilakukan di luar pembelajaran dengan menghidupkan budaya baca di lingkungan sekolah, menambah koleksi perpustakaan dengan bacaan sastra bermutu, meningkatkan kreativitas siswa melalui budaya menulis, serta menambah wahana penyalur kreativitas itu, minimal majah dinding atau sudut baca.

\section{DAFTAR PUSTAKA}

Asmani, Jamal Ma'mur. (2011). Buku panduan internalisasi pendidikan karakter di sekolah. Yogyakarta: DIVA Press.

Basir, Udjang Pr.M. (2014). Aspek kesastraan dalam kurikulum sahasa Indonesia: Sejumlah problema ierstruktur. Makalah Seminar. Jember: PS PBSI FKIP Universitas Jember.

Basral, Akmal Nasery. (2010). Sang pencerah, novelisasi kehidupan K.H. Ahmad Dahlan dan perjuangannya mendirikan Muhammadiyah. Jakarta: Mizan Mustika.

Berliner, Gage. (1984). Educational psichology 3rd edition. Houghton Mifflin Company All Right Reserved.
Djuanda, Dadan. (2008). Studi tentang penerapan pendekatan komunikatif dan pendekatan terpadu dalam pembelajaran bahasa Indonesia di kelas VI SD Negeri Sukamaju kabupaten Sumedang. Lurnal Pendidikan Dasar, Nomor 10 - Oktober 2008.

Djuanda, Dadan. (2014). Pembelajaran sastra di SD dalam gamitan kurikulum 2013. Mimbar Sekolah Dasar, Volume 1, Nomor 2, Oktober 2014.

Effendi, Roestam, dkk. (1998). Pembelajaran dan teori apresiasi sastra. Jendela Sastra, Wikipedia, diakses 17-01-2015.

Fitri, Agus Zaenal. (2012). Pendidikan karakter berbasis nilai dan etika di sekolah. Yogyakarta: Ar-Ruzz Media.

Haryati, Sri. (2014). Pendidikan karakter dalam kurikulum 2013. Bangkalan: FKIP - UTM.

Huck, Charlotte. dkk. (1987). Children literature in the elementary school. Chicago: Rand McNally College Publishing Company.

Isjoni. (2010). Pembelajaran kooperatif. Yogyakarta: Pustaka Pelajar.

Kemendikbud. (2013). Peraturan Menteri Pendidikan dan Kebudayaan R. I. Nomor 70 Tahun 2013 tentang kerangka dasar dan struktur kurikulum Sekolah Menengah Kejuruan /Madrasah Aliyah Kejuruan. Jakarta: Kemendikbud.

Kemendikbud. (2013). Silabus mata pelajaran bahasa Indonesia pada satuan pendidikan SMK/MAK kurikulum 2013.. Jakarta: Kemendikbud.

Kemendikbud. (2014). Peraturan Menteri Pendidikan dan Kebudayaan R.I. Nomor 103 Tahun 2014 tentang 
pembelajaran pada pendidikan dasar dan pendidikan menengah. Jakarta: Kemendikbud.

Kemendiknas. (2006). Peraturan Menteri Pendidikan Nasional R.I. Nomor 22 Tahun 2006 tentang standar isi untuk satuan pendidikan dasar dan menengah. Jakarta: Kemendiknas.

Maemonah. (2012). Aspek-aspek dalam pendidikan Karakter. Forum

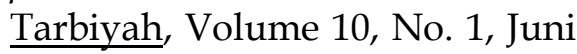
2012.

Mahsun. (2014). Teks pembelajaran bahasa Indonesia K13. Jakarta: Raja Grafindo Persada.

Nusantara, Bondan. (2011). Rembulan ungu tragedi cinta gadis Tionghoa di bumi Mataram. Bandung: Qanita P.T. Mizan Pustaka.

Oemarjati, Boen S. (1992). Dengan sastra mencerdaskan siswa: memperkaya pengalaman dan pengetahuan. Jakarta: Pustaka Sinar Harapan.

Pritchard, I. (1988). Character education: research prospect and problem. American Journal of Education. Diakses tanggal, 26 September 2015. 

Undas, Vol 14, Nomor 1, Juni 2018: 22-40 